\title{
Inheritance of resistance to Phytophthora infestans (Peronosporales, Pythiaceae) in a new source of resistance in tomato (Solanum sp. (formerly Lycopersicon sp.), Solanales, Solanaceae)
}

\author{
Flávia Barbosa Abreu ${ }^{1}$, Derly José Henriques da Silva ${ }^{2}$, Cosme Damião Cruz ${ }^{3}$ and \\ Eduardo Seiti Gomide Mizubuti ${ }^{4}$ \\ ${ }^{1}$ Universidade Federal de Mato Grosso do Sul, Campus de Chapadão do Sul, Chapadão do Sul, MS, Brazil. \\ ${ }^{2}$ Departamento de Fitotecnia, Universidade Federal de Viçosa, Viçosa, MG, Brazil. \\ ${ }^{3}$ Departamento de Biologia Geral, Universidade Federal de Viçosa, Viçosa, MG, Brazil. \\ ${ }^{4}$ Departamento de Fitopatologia, Universidade Federal de Viçosa, Viçosa, MG, Brazil.
}

\begin{abstract}
In Brazil, no commercial tomato (Solanum lycopersicum L. formerly Lycopersicon esculentum Mill.) varieties are available which are resistant to the late blight, one of the most important tomato diseases, produced by the phytopathogenic oomycete Phytophthora infestans. The wild tomato (Solanum habrochaites Knapp \& Spooner, formerly Lycopersicon hirsutum Dunal) shows resistance to $P$. infestans, because of which we investigated an interspecific cross between S. Iycopersicum cv. Santa Clara and S. habrochaites accession BGH 6902 maintained at the Horticultural Germplasm Bank at the Federal University of Viçosa (Banco de Germoplasma de Horticultura $(B G H)$, Universidade Federal de Viçosa (UFV), Viçosa, Minas Gerais, Brazil) The genitors, $F_{1}, F_{2}, B_{1}$ and $B_{2}$ were used to study the inheritance of resistance to $P$. infestans and to estimate the genetic parameters associated with resistance. Analysis of the area under the disease progress curve (AUDPC) indicated that inheritance is polygenic and that dominance controls character, whereas mean analysis showed that the additive effect was the most important. Although the character presents variability, the heritability is low which generates the need to better control the environment to obtain success with the selection.
\end{abstract}

Key words: late blight, Lycopersicon esculentum, Lycopersicon hirsutum, Solanum lycopersicum, Solanum habrochaites.

Received: March 19, 2007; Accepted: October 4, 2007.

\section{Introduction}

The tomato plant (Solanum lycopersicum L. (formerly Lycopersicon esculentum Mill.) Solanales, Solanaceae) is among the most genetically studied vegetables and improved tomato varieties have increased crop productivity and improved quality. However, late blight, caused by the phytopathogenic oomycete Phytophthora infestans (Mont.) De Bary, is a highly destructive disease and one of the most severe problems in the tomato crop. When the temperature is mild and the humidity high late blight can cause severe epidemics and destroy the entire production of a tomato crop.

Large amounts of resources are used to reduce risk of damage caused by $P$. infestans, with approximately one billion dollars per year being spent on the control of late blight

Send correspondence to Flávia Barbosa Abreu. Universidade Federal de Mato Grosso do Sul, Campus de Chapadão do Sul, Caixa Postal 112, 79560-000 Chapadão do Sul, MS, Brazil. E-mail: flaviaabreu@ nin.ufms.br. control worldwide (Mizubuti and Fry, 2006). In Brazil, an estimated $20 \%$ of the production costs of tomato crops are due to the chemical control of late blight (Mizubuti, 2005). Additional production costs also occur due to the increased quantity of fungicide used or the substitution of cheaper fungicides by more expensive ones because of the emergence or predominance of resistant $P$. infestans strains (Reis et al., 2005).

The lack of tomato cultivars resistant to $P$. infestans is due to the difficulty in working with this phytopathogen in breeding programs because of its high mutation capacity and polygenic resistance (Brouwer et al., 2004). Furthermore, the identification of sources of genetic resistance to $P$. infestans in tomato is difficult. Therefore, genetic resources that can be used as sources of resistance have been searched in germplasm banks.

The Horticultural Germplasm Bank at the Federal University of Viçosa (Banco de Germoplasma de Horticultura (BGH), Universidade Federal de Viçosa (UFV), 
Viçosa, Minas Gerais, Brazil) stores more than 7200 accessions of horticulturally useful plants, 1700 of which are Solanum species (formerly Lycopersicon species) which have yet to be evaluated for resistance to $P$. infestans. Ideally, the identified resistance gene should belong to the genotype of the species to be genetically modified, for easier intercrossing and gene transfer. However, pathogen resistance is often found among wild species. Genes of the wild tomato Solanum habrochaites Knapp \& Spooner (formerly Lycopersicon hirsutum Dunal) accession BGH6902 held at BGH-UFV confer resistance to several tomato pathogens including $P$. infestans (Hassan et al., 1984; Nash and Gardener, 1988; van der Beek et al., 1994).

The introgression of resistance genes from $S$. habrochaites is a viable and promising strategy and breeding studies on the insertion of resistance genes in cultivated tomato germplasm are needed. These studies should be based on knowledge of the inheritance of resistance prior to the acquisition of the resistant lines to be used in tomato plant breeding programs in the future.

In the study described in this paper we determined the inheritance of tomato resistance to $P$. infestans and estimated the genetic parameters associated with resistance to late blight in the crossing of $L$. esculentum and $S$. habrochaites.

\section{Material and Methods}

\section{Plants, crosses and field conditions}

We carried out an interspecific cross between the cultivated tomato (Solanum lycopersicum L.) cultivar Santa Clara $\left(\mathrm{P}_{1}\right)$ and the wild tomato (Solanum habrochaites Knapp \& Spooner) accession BGH6902 $\left(\mathrm{P}_{2}\right)$ from the BGH-UFV collection. The Santa Clara cultivar is one of the most frequently grown cultivars in Brazil, has indeterminate growth and is resistant to various phytopathogens (Fusarium oxysporum f. sp. lycopersici race 1, Verticillium sp. and Stemphylium sp.) and has good resistance to fruit cracking and calcium deficiency. Accession BGH6902 has been identified as being resistant to $P$. infestans in preliminary tests (data not shown) and has small fruits that are greenish when ripe and have an unpleasant flavor and smell, characteristics that make these fruits unsuitable for commercialization.

In April and May 2002, autumn in Brazil, the Santa Clara cultivar and accession BGH6902 were sown and grown to flowering in a greenhouse at a temperature of $20^{\circ} \mathrm{C}$ to $27{ }^{\circ} \mathrm{C}$ and a relative humidity (Rh) of $60 \%$ to $75 \%$. Fertilizer ( $5 \mathrm{~kg} \mathrm{ha}^{-1}$ of zinc sulphate, $200 \mathrm{~kg} \mathrm{ha}^{-1}$ of magnesium sulphate, $300 \mathrm{~kg} \mathrm{ha}^{-1}$ of ammonium sulphate, $1400 \mathrm{~kg}$ $\mathrm{ha}^{-1}$ of P2O5 and $20 \mathrm{~kg} \mathrm{ha}^{-1}$ of potassium chlorate) was applied and the plants were sprayed with the equivalent of $600 \mathrm{~L} \mathrm{ha}^{-1}$ of the fungicide Ridomil Gold MZ (Syngenta, Brazil) at 35 days and 45 days post-emergence. At flowering, cultivar BGH6902 was used as pollen supplier for
Santa Clara to obtain the $F_{1}$ generation, which was selfpollinated and sown to produce the $\mathrm{F}_{2}$ generation and backcrossed $(\mathrm{BC})$ with the Santa Clara parent to produce the $\mathrm{BC}_{1}$ and backcrossed (BC) with the BGH6902 parent to produce the $\mathrm{BC}_{2}$ generation. In all cases the greenhouse conditions and treatment of the plants were the same as for the parents. In May 2003, seeds of all six populations were sown in polystyrene trays containing Plantmax ${ }^{\circledR}$ substrate.

In June 2003 (winter) at 30 days post-emergence the seedlings were transplanted to plots in a 0.04 ha experimental field (2045'14" S, 42 ${ }^{\circ} 52^{\prime} 53^{\prime \prime} \mathrm{W}$, altitude $648,74 \mathrm{~m}$, soil type cambisoil) belonging to the Universidade Federal de Viçosa, in Viçosa, Minas Gerais State, Brazil. Throughout the evaluation of late blight severity among the populations under study, the temperatures ranged from $13.8{ }^{\circ} \mathrm{C}$ to $21.2{ }^{\circ} \mathrm{C}$ (mean $16.7^{\circ} \mathrm{C}$ ) and $\mathrm{Rh}$ from $67 \%$ to $93 \%$ (mean $76 \%$ ), which are considered adequate for the development of late blight (Mizubuti and Fry, 2006).

The experiment design was totally randomized with 1 $\mathrm{m}$ between lines and $0.8 \mathrm{~m}$ between plants. The number of plants grown were as follows: 19 Santa Clara; 20 BGH6902; $29 \mathrm{~F}_{1} ; 201 \mathrm{~F}_{2} ; 108 \mathrm{BC}_{1}$; and $134 \mathrm{BC}_{2}$. All recommended cultural practices for the crop were undertaken, the plots being fertilized with $5 \mathrm{~kg} \mathrm{ha}^{-1}$ of zinc sulphate, $200 \mathrm{~kg} \mathrm{ha}^{-1}$ of magnesium sulphate, $300 \mathrm{~kg} \mathrm{ha}^{-1}$ of ammonium sulphate, $1400 \mathrm{~kg} \mathrm{ha}^{-1}$ of P2O5 and $20 \mathrm{~kg} \mathrm{ha}^{-1}$ of potassium chlorate and the plots sprayed at 40 days and 50 days post-emergence with the equivalent of $600 \mathrm{~L} \mathrm{ha}^{-1}$ of the fungicide Ridomil Gold MZ (Syngenta, Brazil). One stem only was left per plant and hose irrigation was adopted until the day prior to inoculation, after which the plants were irrigated by aspersion to ensure high humidity in the environment.

\section{Production and application of $P$. infestans inoculum}

To detect the source of non-specific resistance and to minimize the potential effects of epistatic vertical resistance genes we inoculated the plants with an inoculum consisting of an approximately equal number of sporangium from each of six $P$. infestans isolates which were known to cause disease in tomatoes and had been isolated from six different tomato producing regions in the Zona da Mata, in the Brazilian state of Minas Gerais.

Infected leaflets were collected and placed on trays previously disinfected with alcohol at $70 \%$ and lined with paper towel dampened in distilled water. Several leaflets were placed in each tray and sprayed with distilled water. The trays were covered with plastic to maintain humidity and kept at $18{ }^{\circ} \mathrm{C}$ for $24 \mathrm{~h}$ to promote sporulation. After sporulation, lesions with mycelium and sporangia were removed, placed in vials containing sterilized distilled water and vortexed to obtain a sporangia suspension. Sporangium suspensions were prepared for each $P$. infestans isolate and the number of sporangium adjusted to $10^{3}$ per $\mathrm{ml}$ by counting in a hemocytometer and appropriate dilution with dis- 
tilled water. A mixed sporangium inoculum was prepared using the same volume of each of the suspensions and allowed to stand at approximately $4{ }^{\circ} \mathrm{C}$ for $1 \mathrm{~h}$ to stimulate zoospore formation. The time between the preparation of the inoculum and inoculation of the tomato plants in the field did not exceed two hours so that zoospores would not lose viability. After standing, the spore suspension was poured into a $20 \mathrm{~L}$ back sprayer (Guarany, Brazil) and used to inoculate the tomato plants with approximately $10 \mathrm{~mL}$ of inoculum for each plant. The tomato plants were inoculated in August 2003, 60 days after the transplantation of the plantlets, and evaluations carried out every three days, for 6 times, until the plants were 78 days old.

Evaluation of disease severity was undertaken by two independent assessors trained to use the Severity PRO program (Nutter, 1997) and to correct inaccuracies which can occur during the visual assessment of disease severity. The severity of late blight in each plant was estimated as the percentage of affected plant tissue in each plant leaf, the overall evaluation being the mean grade value for all the leaves on each plant.

\section{Data analysis}

To obtain estimates of the genetic resistance parameters the area under the disease progress curve (AUDPC) values (Sharner and Finney, 1977) were analyzed using the GENES program (Cruz, 2001). The analysis of means was obtained using the method of Mather and Jinks (1984) and the minimum number of genes that determine the character was estimated using the formula derived by Burton (1951):

$$
\eta=\frac{R^{2}}{8 \hat{\sigma}_{a}^{2}}
$$

where $\hat{\sigma}_{a}^{2}=$ additive variance and $R=$ the total width of the $\mathrm{F}_{2}$ (value in $\mathrm{F}_{2}$ minus the smaller value in $\mathrm{F}_{2}$ ).

The t-test was used to test for significant differences between means (Cruz et al., 2004).

\section{Results and Discussion}

After the analysis of generation means using the Mather and Jinks (1984) method, the complete model (genetic parameters [m], [d], [h], [dd], [dh] and [hh]) and the dominant additive model (parameters $[\mathrm{m}],[\mathrm{d}]$ and $[\mathrm{h}]$ ) were tested to assess the importance of the epistatic effects on the genetic control of the traits studied. The parameters [m], [d] and $[\mathrm{h}]$ represent mean of homozygous, additive genic effect and non-additive genic effect respectively.

After the analysis of generation means, the dominant additive model with the $[\mathrm{m}]$, [d] and [h] parameters was tested to assess the importance of the effects on the genetic control of the traits studied. In this model, the three estimated parameters $([\mathrm{m}],[\mathrm{d}]$ and $[\mathrm{h}])$ differed significantly from zero by the t-test at the $1 \%$ probability level, where the mean was the highest estimate parameter and the genic ef- fect due to dominance was the highest variance parameter (Table 1).

The mean, additive and dominance effects explained $97.72 \%$ of the available variability in the complete model, while epistatic effects represented less than $3 \%$ of the total variability and were not important for the inheritance of resistance. This indicates that an additive-dominance model was suitable for explaining the data for the raction of plants to $P$. infestans. According non-orthogonal decomposition of the sum of squares of parameter, the model showed that the mean effect explained about $71 \%$ of the available variability and the additive effect explained almost 25\% (Table 2).

The late blight symptom AUDPC mean was 319 for susceptible Santa Clara cultivar and 79 for the resistant accession BGH6902, illustrating the differences between the two genitors in terms of resistance to $P$. infestans. Late blight severity values of the $\mathrm{F}_{1}, \mathrm{~F}_{2}, \mathrm{BC}_{1}$ and $\mathrm{BC}_{2}$ generations were similar to the values for their genitors (Table 3 ).

The variances were obtained for each generation (Table 3 ) and estimates of additive variance, variance due to dominance deviation, mean dominance degree, broad and narrow senses heritability and the number of genes that control character were calculated (Table 4).

The estimated additive variance (1112.29) was smaller than the variance due to dominance deviations

Table 1 - Additive dominant model genetic effects estimates for the parental $\left(\mathrm{P}_{1}, \mathrm{P}_{2}\right)$, filial $\left(\mathrm{F}_{1}, \mathrm{~F}_{2}\right)$ and backcross $\left(\mathrm{BC}_{1}, \mathrm{BC}_{2}\right)$ generations of the tomato cross 'Santa Clara' x BGH 6902. The estimates were based on the area under the disease progress curve (AUDPC) for late blight caused by Phytophthora infestans. The parameters [m], [d] and [h] represent mean of homozygous, additive genic effect and non-additive genic effect respectively.

\begin{tabular}{lccc}
\hline Parameter & Mean & Variance & t-test \\
\hline$[\mathrm{m}]$ & 213.16 & 69.30 & $25.61 * *$ \\
{$[\mathrm{~d}]$} & 118.97 & 60.45 & $15.30^{* *}$ \\
{$[\mathrm{~h}]$} & 87.86 & 274.03 & $5.31 * *$ \\
\hline
\end{tabular}

**Significant at $\mathrm{p}=0.001 \%$.

Table 2 - Non-orthogonal decomposition of the model sum of parameter squares adjusted for area under the disease progress curve (AUDPC) for late blight caused by Phytophthora infestans in the parental $\left(\mathrm{P}_{1}, \mathrm{P}_{2}\right)$, filial $\left(\mathrm{F}_{1}, \mathrm{~F}_{2}\right)$ and backcross $\left(\mathrm{BC}_{1}, \mathrm{BC}_{2}\right)$ generations of the tomato cross 'Santa Clara' x BGH 6902. The parameters [m], [d] and [h] represent mean of homozygous, additive genic effect and non-additive genic effect respectively.

\begin{tabular}{lccc}
\hline Source of variability & Sum of squares & $\mathrm{R}^{2}(\%)^{1}$ & Adjusted effect \\
\hline$[\mathrm{m}] /[\mathrm{d}],[\mathrm{h}]$ & 655.68 & 71.43 & 213.16 \\
{$[\mathrm{~d}] /[\mathrm{m}],[\mathrm{h}]$} & 234.12 & 25.50 & 118.97 \\
{$[\mathrm{~h}] /[\mathrm{m}],[\mathrm{d}]$} & 28.17 & 3.07 & 87.86 \\
\hline Total & 917.97 & &
\end{tabular}

${ }^{1}$ Correlation coefficient of multiple determination. 
Table 3 - Estimates of the means and variances for the severity of late blight caused by Phytophthora infestans in the parental $\left(\mathrm{P}_{1}, \mathrm{P}_{2}\right)$, filial $\left(\mathrm{F}_{1}\right.$, $\left.\mathrm{F}_{2}\right)$ and backcross $\left(\mathrm{BC}_{1}, \mathrm{BC}_{2}\right)$ generations of the tomato cross 'Santa Clara' x BGH 6902.

\begin{tabular}{lcrrrl}
\hline $\begin{array}{l}\text { Genera- } \\
\text { tion }\end{array}$ & $\begin{array}{c}\text { Number } \\
\text { of plants }\end{array}$ & Mean & Variance & $\hat{V}(\hat{m})$ & $1 / \hat{V}(\hat{m})$ \\
\hline $\mathrm{P}_{1}$ & 19 & 319.16 & 4990.81 & 262.67 & 0.0038 \\
$\mathrm{P}_{2}$ & 20 & 79.45 & 1956.47 & 97.82 & 0.0102 \\
$\mathrm{~F}_{1}$ & 29 & 248.52 & 7609.04 & 262.38 & 0.0038 \\
$\mathrm{~F}_{2}$ & 201 & 273.60 & 12275.22 & 61.07 & 0.0164 \\
$\mathrm{BC}_{1}$ & 108 & 312.45 & 12245.45 & 113.38 & 0.0088 \\
$\mathrm{BC}_{2}$ & 134 & 211.50 & 11192.70 & 83.53 & 0.012 \\
\hline
\end{tabular}

(5621.59) and represented approximately $16.5 \%$ of the genotypic variance (Table 4). The occurrence of dominance in the control of the trait being studied (AUDPC) can be seen in the frequency distribution graph, divided into $\mathrm{F}_{2}$ population classes (Figure 1). The frequency distribution curve could be normal and unimodal if the dominance deviations represented by the two peaks had not occurred.

The broad-sense heritability estimates led us to conclude that $54.86 \%$ of the total variation in the $\mathrm{F}_{2}$ population was due to genetic causes and $9.06 \%$, to additive genetic causes, i.e., narrow-sense heritability (Table 4). Low heritabilities are common in quantitative traits due to the importance of the environmental effect on the performance of the trait being studied (Ramalho et al., 2000).

Susceptibility to late blight showed heterosis, as witnessed by the fact that although the $\mathrm{F}_{1}$ hybrids had AUDPC values intermediary between those for the susceptible and the resistant genitors the values were closer to the Santa Clara susceptible genitor (Table 4).

Table 4 - Estimates of the genetic parameters of late blight caused by Phytophthora infestans in the parental $\left(\mathrm{P}_{1}, \mathrm{P}_{2}\right)$, filial $\left(\mathrm{F}_{1}, \mathrm{~F}_{2}\right)$ and backcross $\left(\mathrm{BC}_{1}, \mathrm{BC}_{2}\right)$ generations of the tomato cross 'Santa Clara' x BGH 6902. The maximum and minimum area under the disease progress curve (AUDPC) for late blight caused by Phytophthora infestans is also shown.

\begin{tabular}{lc}
\hline Parameters & Estimates \\
\hline Phenotypic variance & $12275.22 \pm 1221.43$ \\
Environmental variance & $5541.34 \pm 812.98$ \\
Genotypic variance & $6733.88 \pm 3711.40$ \\
Additive variance $\left(\hat{\sigma}_{a}^{2}\right)$ & $1112.29 \pm 3251.91$ \\
Variance of the dominance deviation $\left(\hat{\sigma}_{D}^{2}\right)$ & $5621.59 \pm 3992.47$ \\
Broad-sense heritability $(\%)$ & $54.86 \pm 0.45$ \\
Narrow-sense heritability $(\%)$ & $9.06 \pm 0.25$ \\
Heterosis & 49.21 \\
Average degree of dominance & 3.18 \\
(based on variances) & \\
Maximum AUDPC value in the $\mathrm{F}_{2}$ generation & 550 \\
Minimum AUDPC value in the $\mathrm{F}_{2}$ generation & 45 \\
Number of genes & 28.66 \\
\hline
\end{tabular}

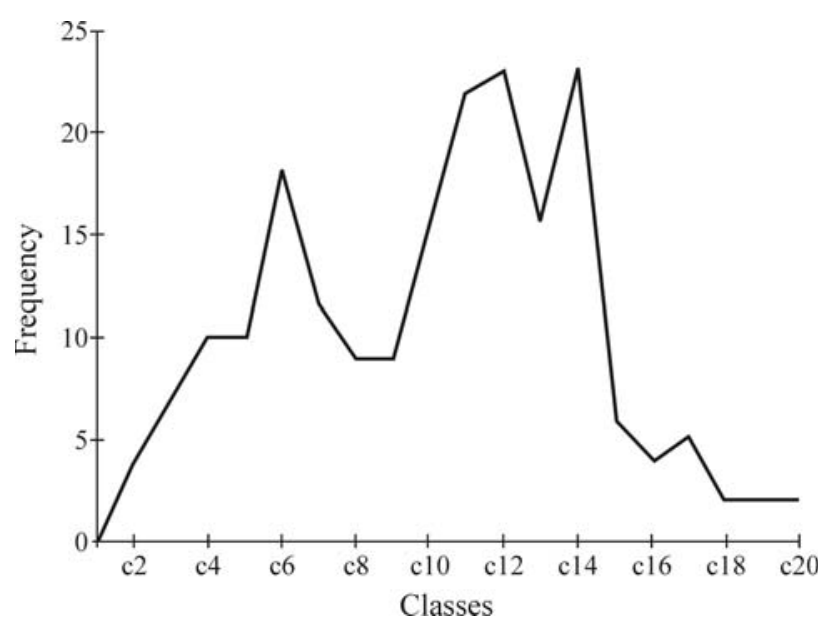

Figure 1 - Frequency distribution of area under the disease progress curve (AUDPC) values for late blight caused by Phytophthora infestans in $\mathrm{F}_{2}$ generation of the tomato cross 'Santa Clara' x BGH 6902. The values were divided into 20 classes evenly distributed in the 45 to 550 interval.

As based on the variances the estimated degree of mean dominance was 3.18 , indicating overdominant genic action (Table 4) but when the estimated degree of mean dominance was based on the means the mean dominance was 0.4 , indicating a partially dominant genic action. The predominant genic effect appeared to be different when subjected to mean or variance analyses. Mean analysis resulted in a low importance of the genic effect due to dominance (Tables 2), whereas the analysis of variance resulted in more important dominance deviations than additive variance (Table 4). The positive sign indicates that dominance was predominant over susceptibility, and not for resistance, that would be more interesting. The contrasting results of the analyses suggest the occurrence of dominance deviations in different directions. The discrepancies in the results calculated using means and variances can also be explained through the possibility of unbalance of linkages of genes in repulsion in $F_{2}$ (Kearsey and Pooni, 1996).

The high error associated with the additive and dominance variance estimates $\left(\hat{\sigma}_{a}^{2}=1112.29 \pm 3251.91\right.$ and $\left.\hat{\sigma}_{D}^{2}=5621.59 \pm 3992.47\right)$ may also explain this contrast between the data produced by mean and variance analysis (Table 4). Variances components can present low precision and in many cases the error exceeds the estimated mean. Because of the error which may be associated with additive and dominance variance estimates, it is probable that the degree of mean dominance is sometimes overestimated. Ramalho et al. (1993) and Cruz et al. (2004) noted that variances, second order statistics, are more reliable for this type of analysis because means do not always represent reality since positive and negative results can nullify each other.

In tomato, inheritance of resistance to other pathogens such as Ralstonia solanacearum, which causes bacterial wilt, and Colletrotichum coccodes, which causes anthracnose, is also quantitative with partial dominance of 
the alleles conditioned for a high AUDPC value (Stommel and Haynes, 1998; Neto et al., 2002).

Our evaluation of $P$. infestans late blight AUDPC values for tomato suggested that 28 genes, a large number, was involved in the control of resistance (Table 4), indicating that resistance to $P$. infestans in tomato follows a polygenic inheritance pattern, thus supporting previous research results (Gallegly and Marvel, 1955; Moreau et al., 1998). For Ramalho et al. (2000), most genes involved in the control of quantitative traits can not have isolated effects and are greatly affected by the environment. However, in our study the additive variance error was 2.9 times the variance value, also very large, which can lead to the rejection of narrow-sense heritability and therefore an over-estimation in the number of tomato genes involved in resistance to late blight.

The continuous distribution of AUDPC values, from resistance to susceptibility, in segregating generations derived from the cross between $S$. esculentum $\mathrm{x} S$. habrochaites lead us to the conclusion that resistance to $P$. infestans is controlled polygenically. The analysis of variances and genetic parameters suggests that this kind of resistance is inherited quantitatively.

\section{Acknowledgments}

We thank the The Brazilian National Counsel for Scientific and Technological Development (Conselho Nacional de Desenvolvimento Científico e Tecnológico, CNPq) and the Brazilian Higher Education Training Program (Coordenação de Aperfeiçoamento de Pessoal de Nível Superior, CAPES) for funding this research.

\section{References}

Brouwer DJ, Jones ES and St. Clair DA (2004) QTL analysis of quantitative resistance to Phytophthora infestans (late blight) in tomato and comparisons with potato. Genome 47:475-492.

Burton GW (1951) Quantitative inheritance in pearl millet (Pennisetum glaucum). Agron J 43:409-417.

Cruz CD (2001) Programa Genes: Versão Windows - Aplicativo computacional em genética e estatística. Editora UFV, Viçosa, 648 pp.

Cruz CD, Regazzi AJ and Carneiro PCS (2004) Modelos Biométricos Aplicados ao Melhoramento Genético.3rd edition. Editora UFV, Viçosa, 585 pp.

Gallegly ME and Marvel ME (1955) Inheritance of resistance to tomato race 0 of Phytophthora infestans. Phytopathology 45:103-109.
Hassan AA, Mazayd HM, Moustafa SE, Nassar SH, Nakhla MK and Sims WL (1984) Inheritance of resistance to tomato yellow leaf curl virus derived from Lycopersicon cheesmanii and Lycopersicon hirsutum. Hort Sci 19:574-575.

Kearsey MJ and Pooni HS (1996) The Genetical Analysis of Quantitative Traits. 1st edition. Chapman and Hall, London, $381 \mathrm{pp}$.

Mather K and Jinks JL (1984) Introdução à Genética Biométrica. Sociedade Brasileira de Genética, Ribeirão Preto, 242 pp.

Mizubuti ESG (2005) Custo da Requeima. Cultivar - Hortaliças Frutas 32:23-26.

Mizubuti ESG and Fry WE (2006) Potato late blight. In: Cooke BM, Jones DG, Kaye and B (eds) The Epidemiology of Plant Diseases. Springer, Dordrecht, pp 445-471.

Moreau P, Thoquet P, Olivier J, Laterrot H and Grimsley N (1998) Genetic mapping of $P h-2$, a single locus controlling partial resistance to Phytophthora infestans. Mol Plant Microbe Interact 11:259-269.

Nash AF and Gardener RG (1988) Heritability of tomato early blight resistance derived from Lycopersicon hirsutum P.I. 126445. J Am Soc Hort Sci 113:264-268.

Neto AFL, Silveira MA, Souza RM, Nogueira SR and André CMG (2002) Inheritance of bacterial wilt resistance in tomato plants cropped in naturally infested soils of the state of Tocantins. Crop Breed Appl Biotech 2:25-32.

Nutter JRFW (1997) Disease severity assessment training. In: Francl LJ and Neher DA (eds) Exercises in Plant Disease Epidemiology. The American Phytopathological Society Press, St. Paul, pp 1-7.

Ramalho MAP, Santos JB and Zimmermann MJO (1993) Genética Quantitativa em Plantas Autógamas: Aplicações ao Melhoramento do Feijoeiro. Editora UFG, Goiânia, 271 pp.

Ramalho M, Santos JB and Pinto CABP (2000) Genética na Agropecuária. 2nd edition. Editora UFLA, Lavras, 472 pp.

Reis A, Ribeiro FHS, Maffia LA and Mizubuti ESG (2005) Sensitivity of Brazilian isolates of Phytophthora infestans to commonly used fungicides in tomato and potato crops. Plant Dis 89:1279-1284.

Sharner G and Finney RE (1977) The effect of nitrogen fertilization on the expression of slow-mildewing resistance in Knox wheat. Phytopathology 67:1051-1056.

Stommel JR and Haynes KG (1998) Inheritance of resistance to anthracnose caused by Colletotrichum coccodes in tomato. J Am Hort Sci 123:832-836.

van der Beek JG, Pet G and Lindhout P (1994) Resistance to powdery mildew (Oidium lycopersicum) in Lycopersicon hirsutum is controlled by an incompletely-dominant gene Ol-1 on chromosome 6. Theor Appl Genet 89:467-473.

Senior Editor: Ernesto Paterniani

License information: This is an open-access article distributed under the terms of the Creative Commons Attribution License, which permits unrestricted use, distribution, and reproduction in any medium, provided the original work is properly cited. 